Shylashri Shankar. (BA Hons, Delhi University, MA (Cantab) University, PhD Columbia University) is a Senior Fellow at the Centre for Policy Research in New Delhi. Her research interests include constitutionalism and religious freedom, 'activism' and policy making by the judiciary, impact of anti-terror laws on civil liberties, migration of ideas between judiciaries, urbanization and old cities, and the political economy of antipoverty initiatives. She is the author of Scaling Justice: India's Supreme Court, Anti-Terror Laws, and Social Rights, Oxford University Press, New Delhi, 2009 and co-author, with Raghav Gaiha, of Battling Corruption: Has NREGA Reached India's Rural Poor, Oxford University Press, New Delhi, 2013.

Contact: shylashris@gmail.com. 


\title{
SECULARITY AND HINDUISM'S IMAGINARIES IN INDIA
}

\author{
Shylashri Shankar \\ Centre for Policy Research, New Delhi
}

Reception date October 20 ${ }^{\text {th }}$ 2014; Acceptance date November $10^{\text {th }} 2014$.

\begin{abstract}
Drawing on Charles Taylor's concept of 'social imaginary' - the kind of collective understanding a group has to have in order to make sense of their practices - the article argues that the contradictions in the Indian Supreme Court's interpretations of Hindutva and Hinduism and in the Indian state's management of religious diversity stem from the inability of the Constitution to reconcile three different imaginaries of Hinduism - as a religion, culture and an ancient order. But these contradictions, while stoking discord, have also provided a buffer zone for the state from such conflicts.
\end{abstract}

\section{Keywords}

social imaginary, secularity, Hinduism, religion, court

\section{Resumen}

Partiendo del concepto de 'imaginario social' de Charles Taylos -es decir, el tipo de comprensión colectiva que un grupo debe tener para darles sentido a sus prácticas-el artículo sostiene que las contradicciones que emergen de las interpretaciones de la Corte Suprema de la India y del Hinduismo y de la gestión de la diversidad religiosa del Estado de la India proceden de la incapacidad de la Constitución de armonizar tres diferentes imaginarios del hinduismo -como una religión, una cultura y una antigua orden-. Sin embargo, además de fomentar el desacuerdo, estas contradicciones también proporcionan una zona franca para el estado de estos conflictos.

\section{Palabras clave}

imaginario social, secularización, hinduismo, religión, Corte. 


\section{Introduction $^{1}$}

The continuing relevance of religious beliefs and politicized religion in countries like India where economic liberalization has marched alongside muscular nationalism (or in Charles Taylor's words, confessionally defined nationalism), requires us to revisit the claim that secularization - the process of the emergence of an 'unbelieving ethos' or the decline/privatization of religion - occurs with modernization. Since the 1990s, the Bharatiya Janata Party (BJP) and its battlecry of Hindutva - a literal meaning is Hindu-ness - has been a forceful contender in India's political arena, having led coalition governments in 1996, and 1998-2004, and a majority government from 2014. The Indian Supreme Court's judgments in three recent cases illuminate the problems caused by politicized religion. In 1996, two cases (henceforth Hindutva Case) were heard together by the Supreme Court of India on whether the use of the term 'Hindutva' in election speeches by the winning candidates was illegal because it pertained to religion, and contravened a law that forbade the use of religious rhetoric in election speeches. ${ }^{2}$ In response, the two politicians (Prabhoo and Joshi) who belonged to the Shiv Sena party (also part of the family or coalition of Hindu chauvinist parties and organizations that include the BJP and the RSS) argued that the concept of Hindutva was cultural and nationalistic rather than religious. Citing the difficulty of defining a Hindu, the

Chief Justice of India, J.S.Verma concluded that the term 'Hindutva' and 'Hinduism' could not be equated with narrow fundamentalist religious bigotry.

«Ordinarily, Hindutva is understood as a way of life or a state of mind and it is not to be equated with, or understood as religious Hindu fundamentalism... the word 'Hindutva' is used and understood as a synonym of 'Indianisation', i.e. the development of uniform culture by obliterating the differences between all the cultures coexisting in the country....» (par. 40)

The answer to whether the use of the word 'Hindutva' in an election speech is religious or not depends on the context, said the judgment. The mere word itself ought not to be narrowly construed as a religious term "unless the context of a speech indicates a contrary meaning or use".

\footnotetext{
${ }^{1}$ I am grateful to Subhadra Banda for research assistance.

${ }^{2}$ Dr. Ramesh Yeshwant Prabhoo vs. Prabhakar K. Kunte AIR (1996) SC 1113; Manohar Joshi vs. Nitin Bhaurao Patil (1996) 1 SCC 169. The Constituent Assembly's decision that religion would be delinked from politics was codified in Section 123(3) of the Representation of People Act (1951), which forbade the use of religious rhetoric in election campaigns.
} 
In the abstract, said the Court, "these terms are indicative more of a way of life of the Indian people and are not confined merely to describe persons practicing the Hindu religion as a faith." ${ }^{3}$ In the case of Prabhoo, the court ruled that the speeches amounted to corrupt practices under the Act, while in Joshi, it did not. In the latter case, the court equated Hinduism - which it saw as

'Indianisation' or culture - with Hindutva, which was deemed to be non-religious nationalist rhetoric.

None of the earlier judgments had equated 'Hindutva' with 'Hinduism'. The judgment was criticised for giving legitimacy to Hindu nationalist ideology, with the upshot being Hindutva = Hinduism = way of life and not a religion = Indianisation $=$ development of a uniform culture, even if the judges themselves may not have meant to say so. ${ }^{4}$ Not surprisingly, the Hindu right viewed the ruling as giving judicial imprimatur to 'Hindutva' as an ideology that expressed nationalism and Indianness rather than a religion, and legitimizing its use in politics. ${ }^{5}$ What made the Hindutva judgment even more ironical is that in a previous judgment (Bommai $v$ Union of India), the

Supreme Court recognized the potential of 'Hindutva' as a divisive religious mobilizing concept. ${ }^{6}$ In Bommai, the Court reviewed the constitutionality of the dismissal of several BJP-led state (subregional) governments for participating in unsecular activities. The dismissal came in the wake of riots between Hindus and Muslims in these states following the destruction of an ancient mosque in northern India. The Court ruled that a state government pursuing an unsecular policy was acting contrary to the constitutional mandate and could be dismissed under Article 356. 'Unsecular' activities included a political party's ideological plank (in this case BJP's Hindutva) in elections that had the effect of eroding the secular philosophy of the Constitution. «If a political party espousing a particular religion comes to power, that religion tends to become, in practice, the official religion. All other religions come to acquire a secondary status, at any rate, a less favourable position ....under our Constitution, no party or organization can simultaneously be a political and a religious party. It has to be either» ${ }^{7}$.

The judgements resulted in a paradox. The BJP was implicitly granted recognition as a political party (Hindutva judgement) and condemned as a religious party (Bommai judgement), though the court in Bommai maintained that no party could be a religious and a political party. How

\footnotetext{
${ }^{3}$ Prabhoo vs. Kunte, (1996) 1 SCC 130:161, Para 43.

${ }^{4}$ A. Nauriya, "The Hindutva Judgments: A Warning Signal”, in Economical and Political Weekly, 31, 1996, pp. 1013.

${ }^{5}$ Asserting that Hindutva was synonymous with nationalism and "Bharateeyatva," party leader Atal Bihari Vajpayee pointed out in a public meeting that the concept did not merit further debate as the Supreme Court had defined it in totality in its judgment. (Times of India, June 7, 1996).

${ }^{6}$ Bommai vs. Union of India (1994) SC 1918.

${ }^{7}$ Ibid., p. 236
} 
do we understand these inconsistencies in the court's interpretations? Should we attribute it to the whims of individual judges? But of the three justices, one (J S Verma) had ruled in both sets of cases.

Scholars have explained these contradictory rulings under the broad rubric of a "crisis of secularism', caused variously by constitutional ambiguities, colonial rule, social justice concerns of a liberal democratic state, and the disjuncture between an elite-driven normative project and the demands imposed by requirements of democratic consent. ${ }^{8}$ For instance, when the Constituent Assembly decided that India would not be a Hindu state, it did not specify what it meant for the country to be a secular one. The term 'secularism' itself was not incorporated until the $42^{\text {nd }}$ Amendment in 1976. Other inconsistencies are that the Constitution exhorts the state to treat all religions with equal respect and simultaneously charges it to reform unequal religious practices (particularly in Hinduism), and correct historical wrongs perpetrated on the lowest castes (of Hindus) and groups through affirmative action in education, government jobs and political constituencies. ${ }^{9}$ The Indian state seeks to separate religion and politics and also involves itself in the regulation, funding and administration of religious institutions.

A more recent explanation comes from Charles Taylor who in A Secular Age $e^{87}$ argues that for purposes of understanding the struggle, rivalry, or debate between religion and unbelief in Latin Christendom, we have to understand religion as combining three dimensions of transcendence.

«It is our relation to a transcendent God which has been displaced at the centre of social life (Secularity I); it is faith in this God whose decline is tracked in these theories (Secularity II), and the third dimension is the emergence of new conditions of belief ... the sense that there is some good higher than, beyond human flourishing (Secularity III)» ${ }^{88}$.

Taylor argues that with the rise of secularization, 'exclusive humanism' becomes an attractive option, but religion does not wither away or become privatized. Taylor is careful to limit his explanation to the Latin Christian world because "it is very hard to demonstrate that an "unbelieving ethos" could not have arisen in any other religion, nevertheless, it seems to me to be overwhelmingly

\footnotetext{
${ }^{8}$ For more recent debates, see A. D. Needham, R. Sunder Rajan (Eds.), The Crisis of Secularism in India, University of Chicago Press, Chicago, 2006.

${ }^{9}$ About $85 \%$ of Indians are Hindus and occupy a caste within a top-down hierarchy of Brahmin (priest), Kshatriya (warrior/King), Vaishya (trader) and Sudra (farming/lowest castes). The caste system not only determines the individual's social status on the basis of the group to which he is born but also differentiates and assigns occupational and economic roles (especially in rural areas). See Louis Dumont's classic Homo Hierarchicus, University of Chicago Press, Chicago, 1981, for a treatise on the organizing principles of the caste system and its implications. ${ }^{87}$ C. Taylor, A Secular Age, Belknap Press of Harvard University Press, Cambridge (Mass.), 2007. ${ }^{88}$ Ibid., p. 20.
} 
plausible" ${ }^{10}$. The plausibility, for Taylor, derives from the absence of enabling conditions, which produced Secularity III in the modern West. He writes:

«An age or society would then be secular or not, in virtue of the conditions of experience of and search for the spiritual. Obviously, where it stood in this dimension would have a lot to do with how secular it was in the second sense, which turns on levels of belief and practice, but there is no simple correlation between the two, as the case of the U.S. shows. As for the first sense, which concerns public space, this may be uncorrelated with both the others (as might be argued for the case of India). But I will maintain that in fact, in the Western case, the shift to public secularity has been part of what helped to bring on a secular age in my third sense In this meaning, as against sense 2, at least many milieux in the United States are secularized, and I would argue that the United States as a whole is. Clear contrast cases today would be the majority of Muslim societies, or the milieux in which the vast majority of Indians live» ${ }^{11}$.

But is Taylor right to lump all the non-Christian societies into a single category? Taylor's and the other explanations do not highlight a more fundamental contradiction, namely how 'Hinduism' is imagined by the Constitution. As we shall see shortly, India epitomises a society where the notions of 'religion' and 'belief' and 'disbelief' are less unambiguous than in Taylor's Latin Christendom, where a belief system (Hinduism) was given the epithet of 'religion' by the colonial power and by some Indian nationalists, and this definition was retained after independence in the country's constitution and laws along with other competing and pre-existing notions of what the belief system constituted including a notion of Hinduism as 'not religion' and of the state governing a public space emptied of God. To explain the contradictions in the judiciary's interpretations of Hindutva and Hinduism and in the Indian state's management of religious diversity, the article draws on a concept used by Charles Taylor, namely 'social imaginaries' - the kind of collective understanding a group has to have in order to make sense of their practices. I argue that the contradictions stem from the inability of the Constitution to reconcile three different imaginaries of Hinduism - as a religion, culture and an ancient order. But these contradictions, while stoking discord, have also provided a buffer zone from which the state can achieve some sort of equi-distance (in Rajiv Bhargava's terms), principled or otherwise, from such conflicts.

\footnotetext{
${ }^{10}$ Ibid., p. 267.

${ }^{11}$ Ibid., pp. 3-4, italics mine.
} 
In the next sections, I highlight three stylized imaginaries of Hinduism - as a religion, an ancient order, and as a western experiential category that is better replaced by the term 'Indian culture'. I show how these imaginaries weave through the Constituent Assembly debates on the role of the new state vis a vis religion, and in the subsequent conflicting interpretations in the political and legal arenas. These imaginaries explain the different interpretations of the courts on the Hindutva cases.

\section{Social Imaginaries of Hinduism}

«I speak of 'imaginary' (i) because I'm talking about the way ordinary people 'imagine' their social surroundings," while "(ii) theory is often the possession of a small minority,...what is interesting in the social imaginary is that it is shared by large groups of people, if not the whole society» ${ }^{12}$.

If one adopts Taylor's distinction between 'theory' and 'social imaginary', then the only way to assess a social imaginary would be to collect accounts of lived experiences of millions of Indians. It is also highly probable that these ethnographies will reveal the presence of not one, but multiple social imaginaries overlapping and jousting with each other. These imaginaries would include, among others, the state's social imaginary constructed by a constitution and interpreted by the courts, religious leaders' social imaginary disseminated through preaching and lectures and practices adopted by the followers, the lived experiences of different types (religions, castes, regions) of ordinary people, and the imaginaries of political leaders displayed through their election manifestoes and speeches and subscribed to by those who vote for them. ${ }^{13}$ Taylor's own approach to experiencing the world and in recounting the transformation of social imaginaries, as Jon Butler points out, stresses ideas and theory more than experience and ordinary people. It is unclear as to who constitutes the "we" in a social imaginary in A Secular Age that «so seldom inquires about the social imaginaries of ordinary people ... as opposed to the social imaginaries described and created by prominent thinkers» ${ }^{14}$

\footnotetext{
${ }^{12}$ Ibid., pp. 171-172.

${ }^{13}$ As weak proxies for ethnographic work, I refer to colonial geographers, travellers and other accounts of the 'Hindoo', and to the biography of a Brahmin savant.

${ }^{14}$ J. Butler, "Disquieted History in A Secular Age," in M. Warner et. al. (eds.), Varieties of Secularism in a Secular Age, Harvard University Press, Cambridge, 2010, p. 198.
} 
This article eschews Taylor's theory-social imaginary dichotomy and focuses on three stylized slices of experiences that have created overlapping and competing imaginaries of 'Hinduism' in India.

\section{(i) Hinduism as a religion}

Sindhu is the term used by ancient Greeks and Persians to referred to peoples (not religions) beyond the river Indus. ${ }^{15}$ European travellers and missionaries regarded Indian traditions as heathen or pagan, and called it 'gentooism', 'the religion of the Hindus,' and then 'Hindooism'/ 'Hinduism' by the end of the eighteenth century. Can Hinduism be called a religion? Sociologist Emile Durkheim defined religion as a unified system of beliefs and practices relative to sacred things, that is to say, things set apart and forbidden - beliefs and practices which unite into one single moral community called a Church, all those who adhere to them. Anthropologist Clifford Geertz viewed religion as a system of symbols which acts to establish powerful, pervasive and long-lasting moods and motivations in men by formulating conceptions of a general order of existence and clothing these conceptions with such an aura of factuality that the moods and motivations seem uniquely realistic. ${ }^{16}$ These definitions imply that there are some conditions that are necessary for something to be called a religion.

Three elements are identified as central to the role played by Europeans in the construction of Hinduism as a religion: a western Christian concept of religion, the idea that Indian religions formed one pan-Indian religion, and the needs of the colonial enterprise. Different religious phenomena came to be seen as parts of one religion, Hinduism, and the core was drawn from Brahmanism - with its texts and priests. ${ }^{17}$ These moves to create a unified religion in India were closely linked to the legal codification of the colonial subject. ${ }^{18}$ Nineteenth century Indian intellectuals who resisted the

\footnotetext{
15 This section's analysis draws from E. Bloch, M. Keppens, R. Hegde, Rethinking Religion in India: The colonial construction of Hinduism, Routledge, London, 2010.

${ }^{16}$ C. Geertz, "Religion as a Cultural System", in M. Banton (ed.) Anthropological Approaches to the Study of Religion, Tavistock Publications, London, 1966.

${ }^{17}$ See articles in V. Dalmia, H. von Stietencron (eds.), Representing Hinduism: The Construction of Religious Traditions and National Identity, Sage, Delhi, 1995.

${ }^{18}$ G. Vishwanathan, "Colonialism and the Construction of Hinduism", in G. Flood (ed.), The Blackwell Companion to Hinduism, John Wiley and Sons, Hoboken (NJ), 2008.
} 
proselytization by Christian missionaries also engaged in constructing a Hindu religion, a modern Hinduism that would be respectable in the eyes of the world and would provide the basis for a morality of acting in the secular world. These reform movements led by and consisting mostly of intellectuals who were Brahmins and part of the elites, transformed Indian traditions into a unified religion, and are held to be precursors of the Hindu nationalists today. ${ }^{19}$

While the constructivist view holds a dominant position, its critics argue that non-Muslim Indians shared a common identity in pre-colonial India $^{20}$, and therefore such identity was coterminous with religious identity. Other shortcomings of the constructivists include ambiguity about the nature of the process of construction, lack of clarity on whether Brahmanism really exists or existed in India, and if it did exist, the absence of answers on why non-Brahmins accepted Brahmanism as their religion, and the absence of a clear relationship between the motives for the construction and the fact of the construction of Hinduism (Keppens and Bloch 2010).

This imaginary of Hinduism as a religion is the one that Taylor refers to, and also informs the Bommai judgment discussed earlier. If this were the only imaginary, then Taylor would be right to say that public secularity (I) has not been achieved in India. Let us now turn to a Hinduism that bears no relation to religion.

\section{(ii) Hinduism as an ancient order}

In The Last Brahmin, Rani Siva Sankara Sarma writes about the views held by his Brahmin savant-father whom he calls "the last Brahmin." 21 The narrator portrays the lived experience of a scholar of the Vedas, to give us a glimpse of a different imaginary. This 'last Brahmin' declares from his deathbed at the age of 80 that neither of his sons is eligible to perform his funeral rites because one (the narrator) is a non-believer, and the other (the narrator's older brother) is a 'Hindu convert' because he espouses Hindu nationalism. The father declares that Brahmins are a people free of - or outside - religion; there is no place for the term 'Hindu' or 'religion' in the canonical Vedic tradition for the followers of the ancient order.

Attempting to understand his father's distinction between Brahmin and Hindu, the narrator asks whether the followers of the ancient order recognized the word Hinduism. The father replies:

\footnotetext{
${ }^{19}$ R. Thapar, "Imaginged Religious Communities? Ancient History and the Modern Search for a Hindu Identity," in Modern Asian Studies, 23, 1989, pp. 209-231.

${ }^{20}$ D.N. Lorenzen, “Who invented Hinduism?', in Comparative Studies in Society and History, 1999, 41, pp. 630-659. In response to the question - what makes this identity into religious identity - Lorenzen replies that religions are associated with a particular emotion or emotional experience that corresponds to Otto's mysterium tremendum et fascinans [a unique point of origin/a personal experience of the sacred], p. 28.

${ }^{21}$ R.S.S. Sarma, The Last Brahmin, trans. D. Venkat Rao, Permanent Black, New Delhi, 2007.
} 
«On the banks of the sacred and serene Krishna river, at a convention of Pandits[scholars], the propriety and impropriety of the term "Hindu" came up for discussion. Then the noble and venerable savant [an illustrious scholar] ... stated through illustrations that the terms Hinduism and Hindu were used first by foreigners, that these words are not related to Bharatiya (Indic) culture. However, grammarians concur that even phonic improprieties have verbal existences. Therefore, when something is absent in the discourse but prevalent in popular usage, the learned must remain indifferent towards such phonic improprieties. When followers of the ancient order who practice varna dharma [caste system] are called Hindus, one should accept this with similar indifference». ${ }^{22}$

Here, the view of Hinduism as an ancient order is based not on religion, but on varna, a classificatory system, that does not allow for entry or exit from the Order. There is no connection between temples and the Brahmins of the ancient order, or between the state and the reform of the classificatory stystem, nor is there any sympathy for Hindu nationalist ideology, which is dismissed as a proxy Christianity and as antagonistic to the aims of the ancient order.

Adherents of this imaginary would say that Taylor's Secularity I and II have no place in the context of Hinduism since God does not exist in public space, and they do not practice religious beliefs. They would also say that they are already engaged in Secularity III - the search for the spiritual.

(iii) Hinduism is an imaginary entity/ Indianness as a culture.

The appropriateness of viewing Hinduism as a religion, and of Brahmanism as its basis is challenged by Balagangadhara who argues that 'religion' is better thought of as a model of 'explanation' that applies only to the Jewish, Christian and Islamic worlds. ${ }^{23}$ This position echoes the views of several travellers and scholars from previous centuries who expressed their inability to understand indigenous practices in India through the lens of religion. Balagangadhara takes five characteristics of religion - a scripture, a standard world view where claims are made on the origin on the world, an authority to settle conflicts, excommunication, and an organization to transmit - and shows how Hinduism does not possess any of these. For instance, the scriptures and texts present multiple stories of the origin of the world; a Rig Veda hymn says, in the ultimate analysis, who created the world does not matter all that much

\footnotetext{
${ }^{22}$ Ibid., p. 61.

${ }^{23}$ S.N. Balagangadhara, "The Heathen in his Blindness... ”: Asia, the West and the Dynamic of Religion, Brill, Leiden, 1994.
} 
«There was neither non-existence nor existence then; there was neither the realm of space nor the sky which is beyond... Whence is this creation? The gods came afterwards, with the creation of the universe. Who then knows whence it has arisen? Whence this creation has arisen - perhaps it formed itself, or perhaps it did not - the one who looks down on it, in the highest heave, only he knows - or perhaps he does not know». ${ }^{24}$

Balagangadhara argues that on other counts too -- no central concept of God, no sole prophet or founder, no authoritative scripture -- Hinduism does not qualify as religion. ${ }^{25}$ So, what is Hinduism? His reply is that it is not possible to formulate the question 'If Hinduism is not a religion, what else is it?' Neither does he replace 'Hinduism' with the term 'culture'. Instead, his claim is the following: Hinduism, the phenomenon constructed by the West, is an experiential entity only to the West and not to us. In this sense, Hinduism is not a part of the Indian culture. It has no existence outside of the western experience of India. ${ }^{26}$ For him, concepts of 'secular', 'secularization' and 'religion' belong to the language of Western Christianity, and those Indian intellectuals and reformers who adopt these terms to discuss Hinduism are 'theologians in a secular guise'. Instead, Balagangadhara prefers to interrogate the subject of an 'Indian culture', a culture without 'religion' in the Christian sense.

For our purposes, Balagangadhara's view can be categorised as an imaginary that sees Hinduism's caste hierarchy as part of an 'Indian culture'. ${ }^{106}$ Such an imaginary would explain the Hindutva judgment discussed at the beginning of the paper, where the Supreme Court equated Hinduism with 'Indian culture' and 'a way of life'.

Let us now examine the interplay between these three imaginaries in the Constituent Assembly's debates on conversion.

\footnotetext{
24 The Poetry of Creation - Rig Veda Book 10 Hymn 129, (10.129), p. 358.

${ }^{25}$ This view seems not to take into consideration the fact that two centuries of a constructed Hindu religion ought to be infused in some fashion in the social imaginary of different groups of modern Hindu Indians. Balagangadhara makes the mistake of treating Christianity as the prototype of 'religion', when all one can say is Hinduism is not a religion like Christianity but one cannot say that Hinduism is not a religion, says Will Sweetman in Hinduism" and the "History of Religion”, Method and Theory in Study of Religion, Brill, Leiden, 15, 2003, pp. 329-353.

26 S.N. Balagangadhara, “Ontological and epistemological commitments of 'Hinduism', March 5, 2011, http://www.hipkapi.com/2011/03/05/ontological-and-epistemological-commitments-of-hinduism-s-n-balagangadhara/ 106 The idiom of culture was also used by V.D. Savarkar, an ideologue of the present day Hindu nationalists, in his book in 1922 titled Hindutva: Who is a Hindu? But he uses it differently from Balagangadhara. Savarkar combines territory (the land of the Indus) with Hindu culture and Hindu people to argue for a reinterpretation of the word Hindu. Thus culture, like the Brahminical world view, also has multiple imaginaries.
} 


\section{India's Constitutional Imaginary}

The 'We, the people...' that constitutions often begin with, implies that the document contains a social (constitutional) imaginary of 'the people' of a country. As mentioned earlier, a major concern for the 207 member Indian Constituent Assembly, many of whom hailed from ordinary backgrounds, was how to douse the flames of religious strife between Hindus and Muslims resulting from the Partition of the country into India and Pakistan. The principle of separation of state and religion generated a lot of opposition within the CA. While the debates recognized the implicit need to separate those aspects of religious dissentions that could demolish democratic stability, there was little agreement on how to achieve this objective. Some saw a secular state as the separation of state and church (religion was not permitted in the public sphere). Others saw it as neutrality of the state towards religion, which could function in the public sphere. A third view maintained that while the state would treat all religions equally, the state had a duty to reform religious practices in line with principles of equality and justice. The texture of the debates in the CA reveals that the members utilized all three imaginaries to argue their case. Those who saw Hinduism as a way of life/culture/an ancient order found themselves on the same side and pitted against those who treated it as a religion. The overlapping and often contradictory pulls of the three imaginaries left their mark on the Indian constitution's conception of the new state's relationship with religion. If Hinduism was treated as a religion, how could the state conform to neutrality and separation of state and religion, and still reform unjust social practices within the Hindu caste system? If Hinduism was an ancient order based on the caste hierarchy, how could the state undertake social justice for the lowest castes? And if Hinduism was part of an Indian culture, how could the state bar it from political discourse? The constitution incorporated all three types of imaginaries, which sometimes coexisted and sometimes collided, producing a resilient buffer zone between the state and religion. The debate on proselytization and conversion in the CA illustrates the point.

Most conversions in independent India occur among the lowest groups in the caste ladder, scheduled castes, and the indigenous peoples, scheduled tribes who aim to improve their low social standing by converting to religions - Buddhism, Islam and Christianity - that promise 'equality'. Conversion presupposes a prior element of propagation. The question of whether the Indian state ought to allow a fundamental right to propagate provoked heated discussions in the Constituent 
Assembly on $3^{\text {rd }}$ December 1948 . The clause discussed was 'the right freely to profess, practice and propagate religion'.

One view was that the state ought not to permit the right to propagate. Two delegates from opposite ends of the spectrum converged on this conclusion. Tajamul Husain, a Muslim who espoused the classic liberal approach of seeing religion as a private affair between man and his God said: «If you start propagating religion in this country, you will become nuisance to others ... I submit, Sir, that this is a secular State and a secular state should not have anything to do with religion». ${ }^{27} \mathrm{~A}$ Hindu delegate, Loknath Misra, said that secularism itself was a «slippery phrase» and «a device to bypass the ancient culture of the land». ${ }^{28} \mathrm{He}$ recommended either banning all religions or choosing Hinduism as the state religion. By allowing propagation, said Misra, the Constitution was paving the way for the complete annihilation of Hindu culture, the Hindu way of life and manners. ${ }^{29}$ His reasoning was that it was not really possible to separate religion from "the ancient culture" of the land.

Those favouring a right to propagate argued their case either on the grounds of a quid pro quo for minorities, or on the assumption of benign and reasoned attempts at conversion or as an integral part of the right to freedom of expression. Lakshmi Kant Maitra, a Hindu, wanted the state to allow propagation because he said that minorities such as Christians, had given up their claims to reserved seats (affirmative action) in the state legislatures in exchange for a right to propagate. Hence, the majority community «should allow this privilege to the minority community and have it for themselves as well». ${ }^{30}$ These debates highlight an ambiguity - how to create a level playing field between proselytizing religions and something (Hinduism) that was seen as a religion and as an ancient culture which one entered by birth and exited by death - that the CA was unable to resolve. The Indian Constitution included the right to propagate (subject to some restrictions) in the fundamental right to religious freedom.

The CA members thus used all three imaginaries in the construction of state-religion relations, peppering the Constitution with contradictions. The Constitution did not define the terms,

'Hindu', 'religion', 'secular' and 'minorities', leaving it to the courts and legislative amendments to do so. In the next section, we shall see how these contradictions produced by the three imaginaries arose to bedevil the judiciary's interpretations of Hinduism and consequently its relationship with a 'secular' state.

\footnotetext{
${ }^{27}$ Constituent Assembly Debates (henceforth CA Debates), 3 December 1948, p. 817.

${ }^{28}$ CA Debates, 6 December 1948, p. 823.

${ }^{29}$ Ibid., p. 824.

${ }^{30}$ Ibid., p. 833.
} 


\section{Judiciary's Interpretations of Hinduism}

\section{(i) Hinduism as a religion and as a culture}

The sect would be 'Hindu' if the individuals were 'Hindus', said a Constitution Bench of the Supreme Court in a case that concerned the identification of an institution as a Hindu institution. ${ }^{31}$ The judges rejected the notion of Hinduism as a religion, and preferred to see it as a culture. Referring to the territorial, not the creedal significance of the term, the judges said that the usual tests applied to a recognized religion or religious creed would turn out to be inadequate in dealing with Hindu religion.

"When we think of the Hindu religion, we find it difficult, if not impossible, to define Hindu religion or even adequately describe it. Unlike other religions in the world, the Hindu religion does not claim any one prophet...in fact, it does not appear to satisfy the narrow traditional features of any religion or creed. It may broadly be described as a way of life and nothing more."

By 1976, the court gave up on trying to define 'Hindu'. «It is a matter of common knowledge that Hinduism embraces within itself so many diverse forms of beliefs, faiths, practices and worship that it is difficult to define the term 'Hindu' with precision». ${ }^{112}$ The legal definition of Hinduism, as legal scholar Marc Galanter points out, is neither a measure of religious belief nor a description of social behavior as much as a civil status describing everyone subjected to the application of "Hindu law' in the areas reserved for personal law.

\section{(ii) Hinduism as a religion and as an ancient order}

In a recent judgment on whether 'Jains' could be classified as a 'minority', the apex court tried but failed to reconcile the imaginaries of Hinduism as a religion and as an ancient order. The rationale

\footnotetext{
${ }^{31}$ Sastri Yagnapurushdasji vs. Muldas Bhudardas Vaishya (1966) 3 SCR 242. ${ }^{112}$

CWT vs. R. Sridharan (1976) 4 SCC 489.
} 
underpinning the dismissal of the appeal to notify the 'Jain' community as a minority highlights the ambiguities introduced by the two imaginaries of Hinduism. ${ }^{32}$

«The word 'Hindu' conveys the image of diverse groups of communities living in India. If you search for a person by name Hindu, he is unidentifiable. He can be identified only on the basis of his caste as upper caste Brahmin, Kshatriya or Vaish or of lower caste described in ancient India as Shudras».

Hinduism, the court said could be called a general religion and common faith of India whereas Jainism was a special religion formed on the basis of quintessence of Hindu religion. «Their only difference from Hindus is that Jains do not believe in any creator like God but worship only the perfect human-being whom they called Tirathankar». The judgment's rationale was that the caste basis of Hindu society meant that no section or distinct group of people could claim to be in majority. «All are minorities amongst Hindus. Many of them claim such status because of their small number and expect protection from the State on the ground that they are backward».

These muddled interpretations replicated themselves in cases dealing with conversions from Hinduism and the retention of affirmative action benefits by such converts. In pursuance of its mandate to deliver social justice to historically discriminated groups, the Constitution provides affirmative action in political constituencies, government jobs and educational institutions to scheduled castes and scheduled tribes. Could those who retained their affiliations to their old communities after converting to another religion (e.g. Christianity) retain their constitutional privileges to affirmative action? The court said yes in the case of scheduled tribe converts to other religions, but no to scheduled caste converts. ${ }^{33}$ For scheduled caste converts, the Supreme Court laid down the norm in Arumugam v Rajagopal, where it said that a caste «is more a social combination than a religious group». This position highlights the conflict between two imaginaries of Hindusim as an ancient order and as a religion. It said that renunciation of Hinduism and adoption of another religious faith did not mean that a person ceased to be a member of the caste in which he was born.

«A caste may consist not only of persons professing Hindu religion but also persons professing some other religion as well, conversion from Hinduism to that other religion may not involve loss of caste, because even persons professing such other religion can be members of the caste [caste as an ancient classificatory system - my interpretation]. This might happen where caste is based on economic or occupational characteristics and not on religious identity or the cohesion of the caste as a social

\footnotetext{
${ }^{32}$ Bal Patil and Anr. vs. Union of India and Ors (2005) 6 SCC 690.

${ }^{33}$ State of Kerala and Anr vs. Chandramohanan (2004) 3 SCC 429.
} 
group is so strong that conversion into another religion does not operate to snap the bond between the convert and the social group». ${ }^{34}$

The above discussion makes the inconsistencies between the court's rulings in the Hindutva cases and the Bommai judgment more comprehensible. These contradictory judgments can be understood within the context of the three imaginaries of Hinduism. Neither the Constitution nor the Representation of People Act (1951) defines 'religion'. The judges in the Hindutva case reviewed previous rulings on what constituted a 'matter of religion', who decided it, and to a lesser extent what constituted a reasonable restriction based on 'public order, morality and health'. They found a mixed bag of rulings. Initially, the courts had allowed religious denominations to decide what constituted a matter of religion, ${ }^{35}$ but had made a distinction between the right to manage affairs in matters of religion (a fundamental right of the religious denomination) and the administration of property (a secular function), subject to state supervision. Later, the court gave itself the right to determine what could or could not be seen as a religious practice, and whether a particular rite was regarded as essential by the tenets of a particular religion. ${ }^{36}$ Social justice concerns for the scheduled castes and tribes compelled the court to curtail the freedom of denominational authorities in 'matters of religion'. For instance, the court upheld the Madras Temple Entry Authorization Act (1948) which allowed scheduled castes to enter a Hindu temple. ${ }^{37}$ Non-essential activities that could be controlled by the state came to include appointment of priests and state legislation on administration of religious institutions. ${ }^{38}$ Thus, as a result of the ambiguities introduced by the three imaginaries on Hinduism, the judiciary gradually expanded the influence of the state over issues that were initially interpreted as 'religious' ones. 39

\footnotetext{
${ }^{34}$ AIR 1976 SC 939, p. 946.

${ }^{35}$ Hanif Quareshi vs. State of Bihar (1958) SC 731; Ratilal vs. State of Bombay (1954) SCR 1055.

${ }^{36}$ Sardar Syedna Taher Saifuddin Saheb vs. The State of Bombay, AIR (1962) SC 853.

${ }^{37}$ Venkataramana Devaru vs. the State of Mysore, AIR (1958) SC 255.

${ }^{38}$ Commissioner, Hindu Religious Endowments vs. Lakshmindra Thirtha Swamiar (1954), SCR 1005.

${ }^{39}$ A similar approach prevailed in the treatment of non-Hindu religions. For instance, in the case of Muslim institutions, the Supreme Court has maintained in almost all cases that regulation of a waqf (Islamic charitable trust) by the state is reasonable.
} 


\section{Hinduism and A Secular Age}

The preceding discussion makes it clear that we can understand the troubled relationship of the Indian state to the management of competing pluralisms only if we parse out the competing imaginaries of Hinduism. The immanent frame of the imaginary of someone like the Brahmin savant who views Hinduism as an ancient order or someone like Balagangadhara who talks about 'Indian culture' would not include Taylor's trio of secularities but could fit into his notion of transcendence and going beyond this life infusing Secularity III. The frame of a Jawaharlal Nehru or B.R.Ambedkar who incorporated a normative project of secularization into the Constitution and removed religion from politics would contain the hope of moving from Secularity I to III.

The Indian case also complicates the notion of social imaginaries used by Taylor in A Secular Age. Concepts of religion/secular, church/state, natural/supernatural could be seen as binaries that originate within Christian theology and do not completely explain or make sense in the non-Christian world. Taylor, perhaps, would not disagree with this statement. In Warner et al., Taylor admits that he «has neglected the way in which western understandings of religion were informed through the precolonial and the colonial encounters with other parts of the world». ${ }^{40}$

Other scholars have analyzed the internal complexity of Hinduism as 'thick and thin religions' (Sudipta Kaviraj), and as 'religion and faith' (Ashis Nandy). Let us examine Kaviraj's analysis because parts of it resonate with the distinction between Hinduism as an ancient order/way of life/culture, and Hinduism as a religion. Kaviraj makes a distinction between thick religion - its internal contents are a vast catalogue of beliefs about large and small things and all of them are crucial to the practice of that particular faith - and thin religion. For Kaviraj, the religion of Hindu nationalists is thin because it is entirely indifferent to the sectarian practices of everyday worship; «indeed its primary purpose is to make them redundant ... There is a certain paradox in the way it orders the world: it uses a broad and inclusive movement for all Hindus and groups linked to Hinduism by their origin; but the entire purpose is to harden and inflame the boundary between this expansive Hinduism and other selected adversaries, particularly Muslims». ${ }^{41}$ He points out the irony that the primary purpose of this inclusion is exclusion of other communities «from a sense of participating in a historically common and interactive religious culture». ${ }^{42}$

\footnotetext{
${ }^{40}$ C. Taylor, Afterword: Apologia pro Libro suo, in M. Warner et.al. (Eds.), Varieties of Secularism in a Secular Age, p. 301.

${ }^{41}$ S. Kaviraj, "On thick and thin religion: some critical reflections on secularization theory," in I. Katznelson, G. StedmanJones (Eds.), Religion and the Political Imagination, Cambridge Univesity Press, Cambridge, 2010, p. 348. ${ }^{42}$ Ibid.
} 
For Kaviraj, an inverse relationship exists between the thickness of religious beliefs and the size of religious communities. In India, it is thin religion that is pervasive, political (not ethical), intolerant (not accommodating) and has the goal of amassing mundane power (not indifferent to power). «It is misleading to hold that in India either religion is becoming stronger, or the secularization thesis is disconfirmed». ${ }^{43} \mathrm{He}$ concludes that the story of Indian modernity, particularly of Hindu religion, shows a process in which a thin Hindu identity seeks to overcome segmentation and produce a collective agency to menace minorities and demand a homogenizing and intolerant version of nationalism. ${ }^{44}$ While Kaviraj's analysis explains the nature of 'Hindu' in Hindu nationalism, it subsumes the notion of Hinduism as an ancient order within the category of religion.

Let us return to a dialogue between a Hindu official and a spiritual leader from The Last Brahmin that explains the notion of Hinduism as an ancient order. «For a genuine practitioner of the ancient dharma, his faith is the same as his mode of living. In his life it is woven into every context. For him there are no separable categories such as social matters and matters of faith».45

Perhaps this faith articulated by the Last Brahmin is the same as the faith alluded to by Ashis Nandy, but different in form and content to the one explicated in Kaviraj's 'thick religion'. Sarma, the narrator of the Last Brahmin analyses Hinduism in modern India as the cultural consequence of colonialism, as a disguised form of Christian monotheism. Within this Hinduism is subsumed Nandy's Hinduism as an ideology, Kaviraj's thin religion, and perhaps parts of Kaviraj's thick religion. So what are we left with in Hinduism as an ancient order as outlined by Sarma? It is a Brahmin tradition, or a social imaginary pertaining to Brahmins, that too a particular type of Brahmin. But it is a powerful one and seems to have influenced apex court judges who tend to be upper caste (Brahmins and Kshatriyas) Hindus. At the same time, it offers us access to a distinct indigenous perspective informed by Sanskrit cultural heritage and literary tradition. ${ }^{46}$

\section{Conclusion}

The ambiguity introduced by the multiple imaginaries of Hinduism has both weakened and strengthened Indian democracy and secularism. Taylor speaks of «belief and unbelief, not as rival

\footnotetext{
${ }^{43}$ Ibid., p. 350.

44 Ibid., p. 354.

${ }^{45}$ R.S.S. Sarma, The Last Brahmin, pp. 191-192.

${ }^{46}$ As the translator points out, the book is written in the voice of the disinherited and non-believing son of the savant.
} 
theories», but as "the different kinds of lived experience involved in understanding your life in one way or the other, on what it's like to live as a believer or an unbeliever» ${ }^{47}$. The imaginaries of Hinduism as a culture and as an Ancient Order are forms of lived experience, which pertain to a third category - one who is neither a believer nor an unbeliever. The existence of this category has simultaneously problematized the state's efforts to manage diversity and increased concerns among scholars and others about a crisis of secularism in India, but has also created a buffer or a zone of ambiguity for the state and prevented it from being torn apart by the fierce battles between majority and minority religions, and between co-religionists. While Taylor's concept of social imaginaries helps us understand the production of these ambiguities, the trajectory of secularities expounded in A Secular Age are less relevant to the Indian context.

Charles Taylor in Modern Social Imaginaries explains the notion of a moral order as carrying a definition not only of what is right, but of the context in which it makes sense to strive for and hope to realize the right (at least partially). ${ }^{48}$ One type of moral order, he says, is based on the idea of the Law of a people, which has governed this people and which, in a sense defines it as a people. The other type of moral order is organized around a notion of a hierarchy in society that expresses and corresponds to a hierarchy in the cosmos. In the Indian case, the imaginaries support different types of moral orders that conflict with each other and with the state's goals. The jostling for dominance by the different imaginaries has acted as a check on the perpetual dominance by one imaginary. For instance, with the election of the NDA coalition led by the Hindu nationalist BJP in 1996, concerns bloomed about the dominance of Hindu nationalism, but by the time the UPA-led coalition took over in the first decade of the $21^{\text {st }}$ century, the specter of muscular Hindu nationalism was less threatening. Today, the ascendance of the Narendra Modi-led BJP government in 2014 has renewed the fears about the exclusion and even victimization of non-Hindus on the one hand, and on the other hand, also produced the hope that a focus on economic revival would inhibit the exclusionary elements of Hindutva.

While a Tayloresque trajectory from Secularity 1 to 3 does not hold explanatory weight for India, Taylor's statement about India being a country that has not yet emptied its public space of religion is partially correct. About $90 \%$ of adult Indians surveyed in a Gallup poll in 2009 said that religion was an important part of their daily lives, but from our preceding discussion, it is unclear which imaginary of Hinduism they are referring to. ${ }^{49}$

\footnotetext{
${ }^{47}$ C. Taylor, A Secular Age, p. 5.

${ }^{48}$ C. Taylor, Modern Social Imaginaries, Duke University Press, Durham, 2004.

${ }^{49} \mathrm{http}$ ://www.gallup.com/poll/142727/religiosity-highest-world-poorest-nations.aspx\#2
} 
What can the state do to tackle the ambiguities? Taylor, in The Power of Religion in the Public Sphere $^{50}$, argues that the point of state neutrality is to avoid favouring or disfavouring not just religious positions, but any basic position, religious or nonreligious. Institutional formulae like the separation of church and state are at best, shorthand heuristics. Instead, constructing a democratic life together may depend more on being able to engage in shared positive pursuits such as exploring ways to work for common goals such as liberty, equality etc. As Craig Calhoun says in his conclusion in the same book, this suggests that we should not understand the public sphere entirely in terms of argumentation about the truth value of propositions, but as a realm of creativity and social imaginaries in which citizens give shared form to their lives together, a realm of exploration, experiment and partial agreements. Scholars like Habermas (who did not discuss religion in his earlier work), Charles Taylor and Judith Butler agree that excluding religion from the public sphere would undermine the solidarity and creativity they seek for citizens. This is not to deny the divisive force of religion or to ignore the insidious effects of religiously biased policies adopted by governments led by parties espousing chauvinist ideologies. Compared to the past, the recent diminishing relevance of caste and religion in winning elections in India is an indicator that the multiple imaginaries associated with Hinduism may have allowed religion to remain in the public sphere without necessarily undermining, in a definitive way, the solidarity and creativity available to citizens.

\footnotetext{
${ }^{50}$ C. Taylor, Why we Need a Radical Redefenition of Secularism, in E. Mendieta, J. Van Antwerpen (Eds.), The Power of Religion in the Public Sphere, Columbia University Press, New York, 2011, pp. 34 ss.
} 